DOI: http://dx.doi.org/10.11157/sites-vol13iss1id304

- ARTICLE -

\title{
VERNACULAR COSMOPOLITANISMS IN SUBURBAN PERIPHERIES: \\ A CASE STUDY IN MULTICULTURAL SYDNEY
}

\author{
Rebecca Williamson ${ }^{1}$
}

\begin{abstract}
This article examines two different articulations of cosmopolitanism that shape everyday spaces in a multicultural suburb in Sydney. The first, top-down cosmopolitanism, is tied to governmental discourses emphasising the value of marketable urban diversity. This is juxtaposed with banal practices of cosmopolitanism in ordinary public spaces. The paper analyses these dynamics in Campsie, a multi-ethnic neighbourhood on the periphery of Sydney's social, political and cultural geographies. The ethnographic examples illustrate the important role that space plays in mediating the performance of vernacular cosmopolitanism a point that is often overlooked in public policy discourses about fostering social cohesion in the city. The paper shows how top-down imaginaries of cosmopolitanism have an ambivalent (sometimes generative, sometimes exclusionary and essentialising) relationship with lived practices of ordinary cosmopolitanism in local spaces. I also argue that vernacular cosmopolitanism can emerge at unexpected sites on the margins of public spaces and events, and need to be accommodated and fostered alongside more ideologically and economically driven strategies for promoting a cosmopolitan ethos of place. Moreover, the beneficiaries of and actors involved in different articulations of cosmopolitanism in a multicultural locale cannot be clearly aligned with class or migrant group; they are as heterogeneous and messy as the demographic composition of a superdiverse neighbourhood like Campsie.
\end{abstract}

Keywords: cosmopolitanism; multiculturalism; urban planning; cities; public space

\section{INTRODUCTION}

Cosmopolitanism is a highly contested term. It folds together a number of social and spatial meanings. In a social and interpersonal sense, it has variously been used to refer to identification with a global community identity, forms 
of intercultural proficiency and the cultural milieu of transnational elites. It has also been defined as an attitude or predisposition - a willingness to 'engage with the Other' or openness toward people, things and experiences that are 'non-local' (Skrbis and Woodward 2007, 730). In a spatial sense, cosmopolitanism can refer to everyday spatial practice oriented around intercultural interaction, as well as an aspirational and attractive element of global city life associated with sites of marketable urban diversity. In this paper I explore two articulations of cosmopolitanism that intersect in a multicultural locale, to examine how they are enfolded in and shaped by ordinary spaces of the city.

I draw on a doctoral study of Campsie, a neighbourhood characterised by a high ethno-cultural mix that is squeezed between the relatively affluent inner west suburbs of Sydney and the sprawling suburbs in the west and southwest of the city. The study investigated the social life of three public spaces in Campsie: a local library, park and pedestrian mall, to analyse how residents from migrant backgrounds reconfigure urban space and conversely, how local spaces shape migrants' experiences of belonging. This study was situated in a broader analysis of how White Australian cultural mores come to create and perpetrate multicultural landscapes in the city.

This paper uses several anecdotal examples from the study to explore vernacular cosmopolitanism (here, referring to spontaneous, informal, locally-specific engagements with the non-local/ethnic Other) and top-down forms of cosmopolitanism (an ideological cosmopolitanism-by-design filtered through the political or economic imperatives of the elite) and how they shape local spaces of multiculture. The first part analyses top-down cosmopolitanism deployed through local place marketing strategies, focusing on the example of a local food festival and a council plan to regenerate Campsie's pedestrian mall. In the second part of the article I examine micro-social interactions in three public spaces (a public park, a weekend Rotary market held in the pedestrian mall, and a women's rest centre) that comprise a ground-up cosmopolitanism: ordinary socio-spatial practices oriented around intercultural exchange that occur in the context of contemporary mobility and multicultural cities.

These illustrations of cosmopolitanism are used to make several points. The first is that there is value in applying the cosmopolitan analytic to everyday spatial dynamics in cities of difference to get a more nuanced picture of how spatial practices - indeed, space itself - shapes intercultural encounters and their attendant imaginaries. A second point is that ordinary cosmopolitanism is often ambivalent; interactions can be fraught or indifferent as well as generative. A third point is that identifying two, somewhat discordant strains 
of cosmopolitanism operating in local spaces does not necessarily translate to discrete populations or groups of actors in a highly economically, socially and culturally diverse neighbourhood. In other words, migrants, non-migrants, working-class and middle-class actors variously enact vernacular and topdown cosmopolitanisms in everyday life.

THEORISING VERNACULAR COSMOPOLITANISMS AND (SUB)URBAN SPACE

Cosmopolitanism has been defined in many ways, and employed for a variety of political, economic and socially progressive ends. It has been used to grasp contemporary transformations in citizenship, belonging and identity associated with globalisation, international migration and transnational lifestyles (Colic-Peisker 2010; Ong 1999; Hannerz 2007). Cosmopolitanism has been identified as a privileged or elective disposition and identity - the preserve of global elites - but has also been associated with vernacular, working-class and non-elective forms of cosmopolitanism (Carruthers 2010; Werbner 1999; Wise 2009; Wessendorf 2010).

Of interest to the current discussion is how these debates drill down to what cosmopolitanism as lived, place-based practice actually constitutes. How are concepts of cosmopolitanism 'grounded' in the everyday life and spaces of the city? Literature on vernacular cosmopolitanism, which examines the routine dimensions of spontaneous encounters across difference, offers a particularly useful lens because it highlights the 'place-ness' of cosmopolitanism, countering the tendency to focus on the 'placelessness' of cosmopolitanism associated with the mobility of a global elite. As Werbner (2006) has written, vernacular cosmopolitanism is an oxymoronic term, joining 'contradictory notions of local specificity and universal enlightenment' (496). In practice, vernacular cosmopolitanism can encompass those 'small achievements in the good city' (Amin 2006, 1012) which include anything from passing greetings between neighbours, exchanges with shopkeepers, chatting in queues or moving over on a park bench for someone to sit down. Moreover, the concept stresses the 'work', competencies and spatial conditions that enable encounters with the 'non-local' (Binnie 2006; Noble 2009; Kesten et al. 2011; Wise and Velayutham 2009; Gilroy 2004). Noble (2009) defines everyday cosmopolitanism as the multiplicity and situatedness of cosmopolitan and transnational identities, as well as the 'forms of situated, strategic, transactional labour' (Noble 2009, 51) involved the negotiation of difference. Such labour can play out in a range of situations and everyday spaces. Wise (2009), for example, shows how exchanging home-grown vegetables across the garden fence constitutes reciprocal relations of caring and interest in the non-local that form the fabric of ordinary 
cosmopolitanism. She focuses on mundane activities that lead to sustained practices of cross-cultural engagement and reciprocity that have the potential to destabilise prejudiced views. Amin $(2002,2012)$ has similarly argued that banal micro-exchanges that tangibly shift people's social perceptions (for example, discriminatory views about another ethnic group), have the potential to foster relations of care and civility in society more generally.

Ordinary cosmopolitanism enlarges the frame of 'living together with difference' to include forms of non-recognition and indifference to difference as well as overt, positive recognition of ethno-cultural difference (as promoted by mainstream models of pluralism and multiculturalism). In other words, it includes relations of distanced respect and non-engagement (Wessendorf 2010) or what Tonkiss (Tonkiss 2003, 299) refers to as an ethics of indifference: 'the capacity to be unseen, to be unexceptional, to be impersonal in a social field where differences remain unassimilated. The assertion that cosmopolitan interaction occurs along a continuum of recognition is useful when considering the examples of intercultural exchange in multicultural suburbs like Campsie.

The intersection between vernacular cosmopolitanisms and the management of space is an area of increasing academic and political interest. Spatial governance and design are inexorably linked to the spatial patterning of encounters across difference and can perpetuate inequalities associated with race, class, age and gender (Duncan and Duncan 2003; Trudeau 2006). The management of public space impacts significantly on how urban citizens recognise the right of other near-dwellers to inhabit urban space (Amin 2002; Fincher and Iveson 2008; Keith 2005; Sandercock 2000). Overt and covert strategies to geographically organise ethno-cultural difference has been amply shown, for example, in studies of planning applications, decisions and zoning (Bugg and Gurran 2011; Anderson and Taylor 2005; Mitchell 1997) and the governance of public space use (Mitchell 1995; Law 2002).

For this reason, Fincher and Iveson (2008) argue that urban planning has a critical role to play in promoting a culture of encounter and recognition across difference. However, they also note that while interaction can be fostered through the design and management of urban spaces, quotidian exchanges cannot be coerced. To be coerced - whether through governmental policy or appropriation by the market - runs the risk of deadening spontaneous, grassroots and transversal interactions (Amin 2002; Wise 2009; Binnie 2006). Thus, while prosaic public spaces can offer 'spaces of enchantment' that bridge differences in the city (Watson 2006), positive inter-ethnic relations do not 
automatically ensue from planned spaces of interaction. As Amin argues in the context of conflict in multi-ethnic British towns, there is a need to recognize the historical relations that also produce urban spaces of multiculture: legacies of migration, poverty, urban politics and national and popular discourses of plurality that might undermine attempts to plan for spaces of cosmopolitan civility and exchange (Amin 2002, 2012).

Vernacular cosmopolitanism is often framed as a more authentic manifestation of openness compared to other, elite expressions of cosmopolitanism. Debate about the normative and moral dimensions of articulations of cosmopolitanism hinges on a key question: who benefits from discourses and practices of cosmopolitanism? Hage (1997) argues that when intercultural encounter is fed into the circulation of global touristic capital it results in a kind of 'cosmo-multiculturalism' - a superficial engagement with a commodified, domesticated and aesthetically pleasing ethnic other. Based on interviews with middle-class restaurant patrons and restaurant owners in Sydney's Vietnamese enclave of Cabramatta, he argues that cosmo-multiculturalism entails the repackaging of everyday migrant home-making practices - those daily cultural practices (often oriented around food) that create a sense of familiarity and security for migrants - for middle-class consumption; a simulated cross-cultural encounter that is largely absent of migrants (Hage 1997). Hage's focus on 'cosmopolitan capital' resonates with contemporary critiques of diversity policies in the neoliberal 'creative city' where the celebration of difference 'enable[s] cities to gain a cutting edge in the service economy' and 'an everyday disposition [is promoted] amongst inhabitants which is geared frequently to gazing upon, eating, talking to and buying otherness' (Edensor 2010, 200). Yet, Hage's thesis has been criticised for missing the role of migrants in this process of place marketing, and for a narrow and moralistic conception of cosmopolitan cultural capital as solely an economic exchange that undermines cultural diversity policy (Brook 2008, 514). Brook (2008) makes an important point that the production of cosmopolitan capital involves a complex set of actors and interests, including local government and migrant groups who benefit in different ways from the promotion of intercultural (economic) exchange.

In what follows I critically engage with these perspectives on the registers of cosmopolitanism through an analysis of some of the locally hewn forms of cosmopolitanism in Campsie. In doing so, I argue that analyses of vernacular cosmopolitan need to consider the particular local configurations of space and how they influence social proximity, as well as how urban places connect into broader social geographies and cultural economies of the city. 
Campsie is a highly diverse suburb that functions as the commercial and administrative centre for the local government area of the City of Canterbury, located approximately seventeen kilometers from Sydney's свD. The suburb sits between affluent inner city suburbs, and ageing, working-class, middle-ring suburbs of Western Sydney, with strong histories of immigration. It has long been shaped by international migration. Post-war migration saw Greek, Italian and Lebanese arriving in the area. In the 1970 it became home to a number of Indo-Chinese refugees, followed by migrants from South Korea, Hong Kong, Malaysia, Taiwan and Mainland China who settled in Campsie in the 1980s. Its proximity to Sydney's dwindling manufacturing bases meant that Campsie initially attracted a lower socio-economic class of groups of migrants from some of these regions (Burnley 2002). More recently, the area has seen arrivals from India, Bangladesh, Indonesia, Nepal and the Pacific Islands.

Campsie's population is highly ethno-culturally diverse: 64 per cent of the total population was born overseas and 89 per cent of people living in Campsie have parents who were born overseas (Australian Bureau of Statistics 2013). The most common birth countries are China (excludes SARs and Taiwan), South Korea, India, Vietnam and Lebanon (Australian Bureau of Statistics 2013). Only 17 per cent of residents speak English at home (Australian Bureau of Statistics 2013). Campsie is a 'gateway suburb': according to the 2011 census, almost one third of the overseas born population arrived in the area after 2006 (compared to 20 per cent in Greater Sydney) (Profile ID and Canterbury City Council 2012). Resident and community workers' narratives reinforce the idea of Campsie as an arrival point in Sydney. During an interview, a local elected councillor noted, 'We have an influx of people coming in and going out - finding their feet then moving on [... this place is] quite transitory' (John, January 2013). Factors attracting migrants to Campsie included its location and direct transport links to the city, affordable housing, the presence of ethnic community groups and businesses, a well-developed infrastructure of agencies providing migrant-related services, and the presence of numerous places of religious worship (mainly Christian). The suburb is also characterised by relatively high socio-economic diversity, and ranks highly on the SEIFA index of disadvantage. ${ }^{2}$ Residents' occupations are highly varied; a third of the population are technicians and trade workers (15.2 per cent) or labourers (14.1 per cent), while 16 per cent are professionals - a relatively low figure compared other parts of the city, but one that represents an increase in recent years.

The notion of peripherality is useful for thinking about Campsie's particu- 
lar brand of cosmopolitanism. While not physically peripheral, it is an area that is economically and symbolically marginalised. Campsie is peripheral to the geographies of the global knowledge economy that attract highly skilled migrants to other parts of the city, although a small, emerging population of temporary, highly skilled migrants are slowly altering the suburb's traditional function as an arrival node for low-skilled and permanent settlers. Campsie also hovers at the edge of processes of urban transformation. At the time of research the suburb was only just showing signs of the gentrification happening in proximate suburbs: there was a decline in housing affordability and an initial influx of aspiring, middle-class homeowners, priced-out of the housing markets in other areas of Sydney, but the area remained marginal compared to the sought-after suburbs close by.

Moreover, Campsie's particular superdiverse ${ }^{3}$ demography means that it is peripheral in Sydney's symbolic economy. It does not easily fit with Sydney's prevailing imaginaries of an ethnic enclave, which are symbolically or demographically dominated by one ethnic group (e.g. Chinatown or Cabramatta's Vietnamese identity). For some time the suburb was marketed as the 'Seoul of Sydney', reflecting a significant South Korean population. However, this phrase has since lost traction as Korean residents have moved out of the area to more affluent suburbs. Some local stakeholders (real estate agents, for example) attempt to brand Campsie as a vibrant ethnic precinct and foodie destination. While it has its own idiosyncratic multiculture and a variety of ethnic food retailers, in practice Campsie remains symbolically distant from the cultural and creative economies that dominate the hip, gentrifying inner suburbs, which are more readily identified as 'cosmopolitan'. Except for its annual food festival, Campsie is not overly noteworthy in the hierarchies of place-based symbolic and cultural capital in Sydney. It is in these senses that I consider Campsie's peripherality and its particular expressions of cosmopolitanism.

\section{METHODS}

This paper draws on a larger study that used a place-based approach to examine issues relating to diversity and place in Campsie. It employed several ethnographic methods. In-depth qualitative interviews were conducted with local residents (six male and ten female) who had migrated to Australia to examine the spatial dimensions of their experiences of local (and national) belonging. As the primary criterion for participation was residence (rather than an ethnic group focus, for example), participants' source countries, migratory trajectories, and period of time in Australia varied. Twenty-one key stakeholders (local council officials, elected councillors, migrant support workers, ethnic com- 
munity representatives and real estate agents) were also interviewed about the management and use of Campsie's public spaces, local multicultural policy and the general transformations that migration had brought about in the suburb. These narratives were analysed alongside participant observation across several key public spaces (a local public library, park and pedestrian mall) and at community events. The study also engaged in photography and participatory map drawing to further investigate how local subjectivities were produced through - and produced - local public spaces.

\section{BRANDED COSMOPOLITANISM AND FASHIONING PUBLIC SPACE}

The first articulation of cosmopolitanism reflects widely circulating discourses of ethno-cultural difference as a form of place-based value in the competitive global city. Through food, signage and other visual cues, this branded cosmopolitanism aims to imbue locality with an attractive, consumable diversity, and is promulgated by local businesses, the council and some residents. Ideally, it attracts well-heeled tourists, highly skilled migrants and an aspirational class of residents to Campsie. Here I briefly describe two examples of how this type of cosmopolitanism is emplaced in Campsie by looking at a local food festival and a regeneration plan for the local pedestrian mall.

Campsie's food festival celebrates the locale as a haven of multicultural diversity. Marketed as 'one of Sydney's premier food festivals', the event is organised by the council with sponsorship from local businesses and other corporate/ state sponsors, and is part of a wave of place-marketing events in Sydney that emerged at the time of the 2000 Sydney Olympic Games. A portion of the main street is closed and Campsie is flooded with a high density of festivalgoers (an average of 15,000 in recent years) who purchase 'ethnic food' from stalls, and take part in other forms of entertainment (eating competitions, cooking demonstrations, noodle making workshops, children's activities and fruit and vegetable carving), or watch ethnic dance and music performances. The festival was initially marketed as a Korean food festival before becoming more pan-ethnic (although strongly Asian) in its orientation. Its stated aims are to 'bring people from all different backgrounds to celebrate not only the harmony between cultures but also celebrate our love for good food.' ${ }^{4}$ Melding pleasurable consumption with socially progressive aims, the festival also offers a conveniently local experience of the non-local: festival-goers are told that they 'won't have to travel far to experience flavours from around the world'.

The audience for these spatial and symbolic articulations of cosmopolitanism is very diverse: there are as many local residents as there are visitors from 
other parts of the city. Some local ethnic business owners and residents readily embrace the festival, connecting it to a sense of local identity and civic pride. Sophia, a local resident and second-generation Greek, commented:

We have this Campsie festival and they dress up in their cultural background clothing and we have performances and stuff like that. You'll really get a feel... that's what I mean about the colour. It's really sensational. I really love being here. (Sophia, November 2012)

Sophia's response was fairly typical. The festival for Sophia was sensorially captivating, educational and gave her a sense of pride of place. Yet, she admitted that she had little actual interaction with other people at the festival, beyond stallholders (many of whom were not local). Other local residents found the festival crowded, slightly alienating and disruptive of their everyday spatial practice. ${ }^{5}$ Several elderly residents from mainland Chinese backgrounds commented that they tended to avoid the festival, as they found the food overpriced and could not sit at their usual benches because of the crowds. Others I spoke to - although in the minority - were more critical of the ideological and economic drive basis of the festival. A business owner who managed a local real estate company found the previous ethnic branding of the festival problematic:

The Council is trying to get a place in the Sydney community for itself - the 'Seoul of Sydney'; come out to our festival, it is better because we are Korean. Whereas you first started to notice that at Chinatown in the city, then it became trendy to be 'Little Italy'. And I don't really think it is trendy to be Korean [...] they haven't got anything really to back it up [...] You can't make it an area that it isn't - you can't make it a place where people want to spend money when it is Two Dollar shops [...] Campsie is like most other places. It's kind of rolling on as the commercial things that happen dictate, and all the council is doing is try to put out a few fires [...] (Jacob, April 2012)

As Sophia's quote demonstrates, some residents experience the type of cosmopolitanism promoted by the food festival as a consumer-friendly, multisensory spectacle that generates a sense of local solidarity and cross-cultural appreciation. The ingestion of exotic food makes the intercultural encounter intimate and thus seemingly more authentic. It is a key trope of Australian multiculturalism - whether seen as a pedagogical tool (Flowers and Swan 2012) or symbolic form of containment and domestication of otherness (Perera 
and Pugliese 1995). But for those without sufficient economic resources or middle-class desire to exploit the cultural capital associated with the festival, like a few of the elderly residents I spoke to, the festival represents a disruption to their everyday engagement in public space. For Jacob, whose knowledge of the local property market and its place in Sydney's symbolic economy allow a more reflexive critique, the festival is experienced as a council-imposed vision of 'trendy' diversity that is somewhat removed from the reality of the suburb and dictated by economic interests.

In the second example I look at a regeneration plan for the local pedestrian mall located in Campsie's town centre. It is a somewhat down-at-heel but wellused public space. In the early morning it provides a socialising point for several groups of elderly migrants from Chinese and South Korean backgrounds who sit and drink tea, watch the world go by, or play checkers on a makeshift table. Mothers and young children meander and play in the mall over the course of the day on shopping and childcare routes, while local workers eat takeaway dumplings on the mall's benches at noon. Small groups of teenagers saunter through the mall after school, while a small group of unemployed individuals noisily (and occasionally drunkenly) take up residence on one of the benches nearest the high street.

In 2012 the council employed a private consultancy firm to assess the viability of converting the mall into a one-way street, and promoting it as a cosmopolitan 'eat-street' with outdoor café-style dining. The plan - not yet realised - was to be partially funded by contributions from residential developments aligning the pedestrian mall. It was, in part, based on an assertion that in its current form the mall attracted anti-social activity and undesirable users. It was proposed that increased 'vibrancy' and 'vitality' could be achieved by converting public space into privatised café spaces and roadways, thus encouraging more desirable middle-class and touristic consumption patterns. The plan drew on comparisons with other 'eat-streets' in Sydney - many located in more affluent (and less ethno-culturally diverse) parts of the city - that aim to rebrand town centres as unique consumption and leisure spaces, often following very similar planning templates.

The initial public consultation involved only twelve participants, mainly from local businesses, and many residents were unaware of the plan. Some residents I spoke to were in favour of the proposed changes; others were concerned about the potential loss of public space and issues of safety if the square was opened to traffic. In the discourse surrounding the plan cosmopolitanism serves as a local economic growth strategy; a tool for localities to justify them- 
selves as economic entities in the context of the competitive global city. As a local elected councillor remarks:

Out of the seventeen suburbs that we have, Campsie seems to make its money ... And it's going to be even better - we're going to have open-air cafes; we are going to have street cafes. I don't know if you know Anglo Road? [the pedestrian mall] [It's] where we have the [food] festival, we are going to open that street. It's going to be more cosmopolitan and draw more crowds. (Gemma, January 2013)

Branded cosmopolitanism fits with the transformation in urban governance to emphasise 'tourism, the production and consumption of spectacles, [and] the promotion of ephemeral events within a given locale', which are the 'favoured remedies for ailing urban economies' (Harvey 1989, 13). But the strategy focused little on the existing multicultural population or everyday patterns of habitation in the mall. The regular users - the elderly, mothers, youth and the unemployed - were marginalised in the plan or labelled as problem populations. Arguably, the strategy runs the risk of prioritising an ill-fitting narrative of marketable, 'appropriate' and convenient cosmopolitanism over the heterogeneous socio-demographic reality and everyday interactions that shape social life in Campsie.

As examples of global city discourses promoting attractive diversity (Murphy, O'Brien, and Watson 2003), the food festival and place-management strategy have an ambiguous relationship with the practices of vernacular cosmopolitanism. On the one hand there is a danger that these place-based strategies funnel attitudes of openness into a narrow consumptive practices that stand in for more substantive and transversal forms of intercultural relationship building, or at least, legitimise popular beliefs that essentialise migrant groups (Anderson 1990, 14). On the other hand, such place marketing strategies do create possibilities for intercultural exchange. The temporary conversion of Campsie's public spaces during the food festival provides heightened opportunities for interaction between residents from a variety of social, economic and ethno-cultural backgrounds, although this intermingling is more likely to demonstrate a distanciated kind of co-presence where a multitude of cultural representatives share urban space, rather than sustained and direct faceto-face contact (beyond economic transactions). It is also possible that the foregrounding of consumer cosmopolitanism in the Anzac Mall plan could be economically and politically productive for migrant groups, otherwise excluded from the circuits of touristic capital. There is a need for further research on the impact of such regeneration schemes on the ethnic economy and on 
migrant communities more generally (see Hall 2015). In other words, there is a danger of glossing these top-down representations of cosmopolitanism as examples of a White middle-class appropriation of ethnic difference, and missing the multiple sets of actors involved in the complex process of urban regeneration and local politics.

However, the cosmopolitanism that the festival and regeneration plan aspire to create are clearly limited in the extent to which they generate 'contact zones' or spaces that foster the day-to-day quotidian transversality that Wise (2009, 22) speaks of. To this end, I look elsewhere in Campsie to find examples of vernacular cosmopolitanism; namely a local park and the local pedestrian mall. While each of these locales have their own sets of micro-spatial politics and divergent publics, each plays an important role in facilitating the mingling of residents from a range of socio-economic and ethnic backgrounds. ${ }^{6}$ The spatial anecdotes that follow offer instances of cosmopolitanism as an unremarkable mode of intercultural competency.

SPACES OF ORDINARY COSMOPOLITANISM

\section{Example 1: Anzac Park}

Anzac Park is located in the town centre but offers something of a respite from the hurried flow of commuters and shoppers. As the name suggests, it was originally designed as a war memorial space and its landscaping is typical of post-war suburban green spaces in Australia. The small park has a playground, band rotunda and benches, and is surrounded in well-tended shrubbery and shaded by several large trees. Ball games and other extensive physical activities are forbidden. Tai chi and calisthenics are popular, and are mainly practiced by elderly residents, many of Chinese migrant backgrounds. Strolling, bench dwelling and children's play constituted the other main activities in the park. Most users saw the park as a friendly, social space. In its unhurried rhythms and retreat-like surroundings, the sociality of the park was characterised by a mixture of modes of interaction. Spontaneous, fleeting friendly encounters (a nodded greeting or exchange of pleasantries) mix with more habituated exchanges as part of semi-formal park activities (such as families regularly visiting the park or the sociality of the tai chi classes). The small size of the park made the space somewhat intimate, yet there was also a general recognition amongst park dwellers of the right to inhabit the space in elective solitude and anonymity - an example of 'dissociation as a certain kind of social relation' (Harris 2014; Tonkiss 2003, 297). 
A conversation with Derek - an Anglo staff member who regularly maintained the park - revealed other instances of habituated intercultural encounter. Derek mentioned that he was friendly with the women who practiced tai chi in the park on weekday mornings. They greet him and exchange pleasantries on an almost daily basis, despite language barriers. He says, 'I had a debate with a guy over the weather, even though we didn't speak the same language!' Derek told me that at the end of the year, the 'tai chi ladies' sometimes gave him a gift (usually toys for his two daughters) with a card. They had also invited him to share food with him during the Moon Festival, setting up a small table in the park. He found that the cuisine, which he was unfamiliar with, 'took some getting used to' but was happy to participate in the celebration for fear of offending the women and their established relations of reciprocity. These moments of intercultural interaction point to the production of the park as a space of transversal encounter in which potentially hierarchical relations (between council staff member and residents) were recast in terms of mutual respect and occasional instances of commensality.

\section{Example 2: The Rotary market}

A temporary market organised by the local Rotary Club takes place every Sunday morning in the pedestrian mall, and represents another space of ordinary cosmopolitanism. Around twenty stalls convert the space into one of informal economic exchange, with products that vary from second-hand goods to jewellery, flowers, household goods, ceramics and plants. There are several sellers from south-eastern Europe (who mainly reside in surrounding suburbs), although the majority of traders are from South Korean, Chinese and Vietnamese backgrounds. Several of the stallholders I spoke to - from Macedonia, Germany and Vietnam - had been attending the market for twenty years. As a long-standing institution, it was a familiar space of social exchange and conviviality between stallholders and customers.

A member of the Rotary club who supervises the market tells me that it is 'very cosmopolitan'. He comments that while several of the vendors are multilingual, organisers sometimes faced language barriers with stallholders. Organisers often relied on the cross-cultural competency of several of the long-term stallholders. Indeed, one of the market managers commented that he regularly consulted a Vietnamese vendor who spoke English and Vietnamese and was able to serve as a 'translator' for other vendors. While these 'transversal enablers' (Wise 2009) smooth the way for practices of vernacular cosmopolitanism, some of the interactions between vendors were still embedded in class relations and staid beliefs about the ethnic Other. Some of the older vendors 
expressed strong views towards incoming groups of migrants - a vendor of East European origin told me the area was being 'invaded' by Chinese migrants - yet, he nonetheless regularly greeted and conversed with fellow stallholders, several of whom were from mainland Chinese backgrounds. For some market participants, these habituated encounters had led to sustained social relationships. Indeed, one previous coordinator of the market - an elderly member of the Rotary club - told me that he returned to the market regularly and exchanged Christmas cards with many of the stallholders he had known for several years.

In a sense, the Rotary Market supports Watson's (2009) suggestion that markets are a 'neglected public space' of social inclusion and 'rubbing along. Longstanding social connections based on shared identities as market vendors were mixed with fleeting encounters that can engender minute forms of recognition, as Watson $(2009,1581)$ argues, 'through a glance or gaze, seeing and being seen, sharing embodied spaces, in talk or silence.' Here cosmopolitanism is a by-product of pragmatic exchange: social exchange emerging in the process of making trade (Hall 2012, 2015). As such, practices of vernacular cosmopolitanism were facilitated by the informal economic exchanges of the market as both a regular event and temporary site of working-class cosmopolitanism.

\section{Example 3: The Women's Rest Centre}

The Women's Rest Centre sits in a nondescript building in the pedestrian mall. It provides a public toilet, baby-changing facilities, seating and community notice boards, and is staffed by an attendant. An average of 350 women use the facility each day, and they reflect the diversity of the area in their composition. Fieldwork revealed the extent to which the rest centre also served as a node of gossip, spontaneous sociality and informal information exchange. Indeed, for some regulars it appeared to be a social destination in itself. When asked if people use it as a social space, an attendant commented: 'yes, people do; they meet friends and sit and chat - use it as a meeting space. Often the same people use it a number of times over the day'. I observed impromptu exchanges about, for example, children's health and schooling, the efficacy of local services, the weather, the politics of local housing developments, and where to buy the best imported clothing in Campsie. I relay one such exchange in my field notes:

While sitting in the Centre today a conversation started with Harriet [a staff member] and a young woman with a young baby. They chat about difficulties of child rearing in general [...] The three of us talk about intergenerational dynamics in families - the young woman 
says her parents and in-laws don't give her a lot of support with her children, despite the fact she has two children under two years of age. A young woman then comes in with a tiny baby, both Cathy and the young mother turn their attention on her. She is taking her baby to the medical centre with a rash, and has to wait for an hour before seeing the doctor. They both look at the child and tell her not to worry. They spend some time reassuring her before [...] joking about their husbands' lack of support with childcare. (Field notes, Wednesday 6 February, 12.30 pm)

This micro-exchange is noteworthy for its spontaneity and for the warmth and care expressed between strangers in an otherwise highly banal community space. As a form of vernacular cosmopolitanism, the rest centre facilitated moments where users could explore multiple forms of commonality: as caregivers, concerned residents and rate-payers, aged citizens, newly arrived migrants etc. While the day-to-day flow of pedestrian traffic in the centre was largely functional and indifferent, moments of congeniality such as this transform the centre into a micro-public space, where forms of 'prosaic negotiation and banal transgression' can occur. Amin $(2002,15)$ argues that these urban spaces have the potential to engender 'moments of cultural destabilisation, offering individuals the chance out break out of fixed relations and fixed notions, and through this, to learn to become different through new patterns of social interaction.' Yet, in the council regeneration plans, the rest centre had only recently been recognised as a community information point; previously it had been classified as a toilet block, supervised by the council's waste management unit. And despite the council's relative strengths in community and multicultural programming, there was little cross-over between city planning imperatives and local social policies. Indeed, the plan for redeveloping the mall suggests that the centre 'may not be the highest and best use in that location, and it might not attract the right mix of people to bring vitality and viability to the Mall' (MacroPlan Australia 2011, 29). Furthermore, it suggests that the site becomes non-gender specific or is converted into a café. In doing so, local government narratives miss the gendered spatial practices of the mall and privilege an ideal future cosmopolitan café culture, populated by middle-class (preferably non-gendered) consumer-citizens.

\section{CONCLUSION}

Campsie is a place where the arrival of new international migrants is not necessarily a noteworthy demographic change (Wessendorf 2010, 16). As such, it demonstrates a type of commonplace diversity that renders ethno-cultural dif- 
ference and migration trajectories 'ordinary', and plays out in everyday spatial encounters between residents. Vernacular cosmopolitanism and its facilitation through the design and management of public spaces are integral to Campsie's social fabric. The small anecdotes discussed above are unremarkable in the context of everyday life in Campsie, but demonstrate important threads of convivial reciprocity and a willingness to experience the 'non-local' that is intimately woven into the fabric of daily life in multicultural locales. The interactions provide something other than the 'exoticised, celebrated and commodified spaces representing visible multicultural settlement' (Watson 2006, 7) - sometimes they are incidental, unexpected and highly banal places. Yet, the importance of fostering such interactions - the very building blocks of what governmental discourses label 'social cohesion' - is often overlooked in the design of public spaces, where cosmopolitanism serves a different, often external audience: would-be residents and investors draw by council visions of Campsie as an exotic foodie haven.

But vernacular cosmopolitan practices are not easily planned for. They defy any easy categorisation as the preserve of a particular social group in Campsie: ground-up expressions of openness and cross-cultural contact can involve long-term migrants, recent arrivals, local government staff, Anglo Australians, the so-called 'elite' cosmopolitan consumers, working-class and marginal social groups. Moreover, conviviality exists alongside hesitant, fraught and tense exchanges. Indeed, this reflects the fact that multiculturalism in its 'raw state' is shot through with ambivalence (Tonkiss 2003; Wessendorf 2010). As Hall $(2015,855)$ argues, 'alongside productive registers of interaction, lurk enduring structures that limit migrant participation through virulent systems of social sorting by class, race, ethnicity and gender'.

So what value is there in recognising these different spatial practices of cosmopolitanism? At one level, the examples in this article reiterate urban revanchist critiques of urban entrepreneurialism that point to the danger of top-down cosmopolitanisms excluding segments of the local population - often marginal groups that fail to fit into local economic growth models that seek to attract the desirable middle-class consumer-citizen (Harvey 1989). Thus, I suggest that place marketing strategies would benefit from more inclusive engagement with and recognition of local populations and their uses of public space, in order to build upon the existing, informal web of ordinary cosmopolitan capital. At another level I have pointed out that top-down cosmopolitanisms are often more complex than merely economically-driven strategies of place marketing: as Brook (2008) has argued, there are many local actors involved in the push for local economies to be associated with a productive 'cosmo-multiculturalism', 
where the local government is often responding to the demands of entrepreneurial migrant groups, as well as local business interests and governmental imperatives (and funding) for social harmony initiatives. The challenge lies, therefore, in the ability of local governments to adequately plan for open and inclusive public spaces that allow space (both literally and symbolically) for the ordinary transversal relations of vernacular cosmopolitanism to take place, as well as the more spectacular and consumer-oriented celebrations of aspirational cosmopolitanism. Ideally, this would involve greater coordination between infrastructural and planning imperatives and multicultural and social programming, not just at the local level, but also at state and national levels.

Campsie's peripheral position in the social, economic and symbolic geographies of Sydney is not intended to cast it as an outlier suburb, but to highlight the potential of other, similar 'in-between' multicultural locales in Australia and elsewhere, and to foster and promote types of 'unpanicked' conviviality (Noble 2009, 51). However, I do not wish to over-romanticise intercultural encounters nor deny the profound inequalities in cities like Sydney. Rather, my focus on the urban conditions that facilitate spontaneous exchange aims to encourage further investigation into the way everyday suburban spaces can serve to de-escalate dysfunctional interpersonal and neighbourhood relations. Can vernacular cosmopolitanisms be scaled up to tangibly influence political discourse and policy? In other words, can mundane social practice 'contaminate political practices... and extend beyond encounter, towards the possibilities of social and political reconfiguration' (Hall 2015, 859)? The extent to which the types of examples discussed here could foster broader politics of civility towards difference (Amin 2012) requires additional debate and further study. However, it is an issue of significant sociological and anthropological importance as cities become increasingly enmeshed in the socio-spatial transformations associated with international mobility and the politics of proximity and diversity.

ACKNOWLEDGEMENTS

The author is grateful for funding provided by the Australian Postgraduate Award scheme and the University of Sydney which supported this research.

NOTES

1 Rebecca Williamson has a PhD in Sociology from the University of Sydney. Her thesis, 'Mundane Multiculture: Belonging as Spatial Practice in Suburban Sydney', examines how everyday practices of multiculturalism are shaped by the 
materiality and sociality of public spaces. Rebecca is working on an Australian Research Council funded project on 'Social Transformation and International Migration', led by Professor Stephen Castles at the University of Sydney. She is currently a Research Associate at Macquarie University on an ARC Discovery Project exploring shared values and 'affinities' in multicultural Australia. She was awarded a Master of Arts in Social Anthropology from Victoria University of Wellington in 2006. She has published papers on methodologies of migration, suburban multiculture and on everyday uses of space.

Email: rwil2924@uni.sydney.edu.au

2 The SEIfA index, developed by the Australian Bureau of Statistics, ranks areas in Australia according to relative socio-economic advantage and disadvantage. Index figures rank Campsie-Clemton Park the fifth most socio-economically disadvantaged out of the sixteen small areas in the City of Canterbury local government area. The City of Canterbury is one of the most disadvantaged local government areas in New South Wales (132nd out of 153 local government areas) (Profile ID and Canterbury City Council 2012).

3 Vertovec's (2006) notion of super-diversity is useful for understanding Campsie's heterogeneity. Super-diversity refers to the increasingly diversified populations of global cities of immigration where 'new conjunctions and interactions of variables' surpass conventional understandings of social and ethno-cultural diversity (Vertovec, 2006, p.2) and lead to new articulations of a 'commonplace diversity' (Wessendorf 2010).

4 Sourced from http://www.campsiefoodfestival.com.au/about/, accessed 31 May 2012.

5 In recent years, festival vendors have only vaguely mapped onto the actual demographic composition of ethnic businesses in the area, and tend to be vendors who regularly circuit multicultural festivals and farmer's markets in the Sydney region.

6 International and national research has identified these quintessential types of prosaic public spaces as important flashpoints for the everyday negotiation of difference in urban space (e.g. Hall 2012; Iveson 2007; Koch and Latham 2012; Low 2000; Low, Tapli, and Scheld 2005).

7 In other work I have discussed how governmental discourses and ground-up intercultural encounters coalesce in a local public library (Williamson 2015). 


\section{REFERENCES}

Amin, Ash. 2002. 'Ethnicity and the multicultural city: living with diversity'. Environment and Planning A no. 34 (6):959-980.

- 2006. 'The good city.' Urban Studies no. 43 (5/6):1009-1023.

- 2012. Land of strangers. Cambridge; Malden, MA: Polity Press.

Anderson, Kay. 1990. 'Chinatown re-oriented': a critical analysis of recent redevelopment schemes in a Melbourne and Sydney enclave.' Australian Geographical Studies no. 18 (2):137-154.

Anderson, Kay, and Affrica Taylor. 2005. 'Exclusionary politics and the question of national belonging: Australian ethnicities in 'multiscalar' focus.' Ethnicities no. $5(4): 460-485$.

Australian Bureau of Statistics. 2013. 2011 Census of Population and Housing Basic Community Profile: Campsie. Australian Bureau of Statistics.

Binnie, Jon. 2006. Cosmopolitan urbanism. New York, NY: Routledge.

Brook, Scott. 2008. 'Cultural capital and cultural diversity: some problems in Ghassan Hage's account of cosmopolitan multiculturalism. Journal of Australian Studies no. $32(4): 509-520$.

Bugg, Laura Beth, and Nicole Gurran. 2011. 'Urban Planning Process and Discourses in the Refusal of Islamic Schools in Sydney, Australia.' Australian Planner no. $48(4): 281-291$.

Burnley, Ian. 2002. 'Evolution of Chinese Settlement Geographies in Sydney, Australia.' Urban Geography no. 23 (4):365-387.

Carruthers, Ashley. 2010. 'Lao Australians on Sydney's urban fringe: a non-cosmopolitan transnationalism?' Amerasia Journal no. 36:1-16.

Colic-Peisker, Val. 2010. 'Free floating in the cosmopolis? Exploring the identity-belonging of transnational knowledge workers.' Global Networks no. 10 (4):467-488. doi: 10.1111/j.1471-0374.2010.00298.x. 
Duncan, James, and Nancy Duncan. 2003. 'Can't Live With Them; Can't Landscape Without Them: Racism and the Pastoral Aesthetic in Suburban New York.' Landscape Journal no. 22 (1): 88-98.

Edensor, Tim. 2010. Introduction: Thinking about Rhythm and Space. In Geographies of Rhythm: Nature, Place, Mobilities and Bodies, edited by Tim Edensor. Farnham, Surrey: Ashgate.

Fincher, Ruth, and Kurt Iveson. 2008. Planning and Diversity in the City: Redistribution, Recognition and Encounter. New York: Palgrave McMillan.

Flowers, R, and S.E. Swan. 2012. 'Eating the Asian Other? Pedagogies of Food Multiculturalism in Australia.' Portal Journal of Multidisciplinary International Studies no. $9(2): 1-30$.

Gilroy, Paul. 2004. Postcolonial melancholia. New York: Columbia University Press.

Hage, Ghassan. 1997. 'At Home in the entrails of the West: Multiculturalism, ethnic food and migrant home-building.' In Home/World: Space, Community and Marginality in Sydney's West, edited by Helen Grace, Ghassan Hage, Lesley Johnson, Julie Langsworth and Michael Symonds, 99-153 Sydney: Pluto Press.

Hall, Suzanne. 2012. City, Street and Citizen: The measure of the ordinary. London; New York: Routledge.

- 2015. 'Migrant urbanisms: ordinary resistence and everyday cities.' Sociology no. $49(5): 853-869$.

Hannerz, Ulf. 2007. 'Foreign Correspondents and the Varieties of Cosmopolitanism.' Journal of Ethnic and Migration Studies no. 33 (2):299-311. doi: $10.1080 / 13691830601154260$.

Harris, Anita. 2014. 'Conviviality, Conflict and Distanciation in Young People's Local Multicultures.' Journal of Intercultural Studies no. 35 (6):571-587.

Harvey, David. 1989. 'From managerialism to entrepreneurialism: the transformation of governance in late capitalism.' Geografiska Annaler no. 71B:3 -17.

Iveson, Kurt. 2007. Publics and the City. Oxford: Blackwell Publishing. 
Keith, Michael. 2005. 'Racialization and the Public Spaces of the Multicultural City' In Racialization, edited by K. Murji and J. Solomos, 249-70. Oxford: Oxford University Press.

Kesten, Jamie, Allan Cochrane, Giles Mohan, and Sarah Neal. 2011. 'Multiculture and Community in New City Spaces.' Journal of Intercultural Studies no. 32 (2):133150.

Koch, Regan, and Alan Latham. 2012. 'On the Hard Work of Domesticating a Public Space.' Urban Studies:1-16.

Law, Lisa. 2002. 'Defying Disappearance: Cosmopolitan Public Spaces in Hong Kong.' Urban Studies no. 39 (9):1625-45.

Low, Setha. 200o. On the Plaza: The Politics of Public Space and Culture. Austin: University of Texas Press.

Low, Setha, Dana Tapli, and Suzanne Scheld. 2005. Rethinking Urban Parks, Public Space and Cultural Diversity. Austin: University of Texas Press.

MacroPlan Australia. 2011. Anzac Mall Place Management Strategy. Campsie, nsw: City of Canterbury.

Mitchell, Don. 1995. 'The End of Public Space? People's Park, Definitions of the Public, and Democracy.' Annals of the Association of American Geographers no. $85(1): 108-133$.

Mitchell, Katharyne. 1997. 'Conflicting Geographies of Democracy and the Public Sphere in Vancouver BC. Transactions of the Institute of British Geographers no. $22(2): 162-179$.

Murphy, Peter, Bette O’Brien, and Sophie Watson. 2003. 'Selling Australia, Selling Sydney: The Ambivalent Politics of Entrepreneurial Multiculturalism.' Journal of International Migration and Integration no. 4(4):471-498.

Noble, Greg. 2009. 'Everyday Cosmopolitanism and the Labour of Intercultural Community.' In Everyday Multiculturalism, edited by Amanda Wise and Selvaraj Velayutham, 46-66. Basingstoke, Hampshire: Palgrave Macmillan.

Ong, Aihwa. 1999. Flexible Citizenship: The cultural logics of transnationality. Durham, NC: Duke University Press. 
Perera, Suvendrini, and Joseph Pugliese. 1995. 'The Limits of Multicultural Representation.' Communal/Plural no. 4:91-113.

Profile ID, and Canterbury City Council. Community Profile: Canterbury City. Canterbury City Council 2012 [cited 4 March 2014.

Sandercock, Leonie. 200o. 'When Strangers Become Neighbours: Managing Cities of Difference.' Planning Theory \& Practice no. 1 (1):13-30.

Skrbis, Zlatko , and Ian Woodward. 2007. 'The Ambivalence of Ordinary Cosmopolitanism: Investigating the limits of cosmopolitan openness.' The Sociological Review no. 55 (4):730-747.

Tonkiss, Fran. 2003. 'The ethics of indifference: Community and solitude in the city' International Journal of Cultural Studies no. 6(3):297-311.

Trudeau, Daniel. 2006. 'Politics of belonging in the construction of landscapes: place-making, boundary-drawing and exclusion.' Cultural Geographies no. 13: 421-443.

Vertovec, Steve. 2006. The Emergence of Super-Diversity in Britain Centre on Migration, Policy and Society, Working Paper 67, http://www.compas.ox.ac.uk/fileadmin/files/Publications/working_papers/WP_2006/WPo625_Vertovec.pdf.

Watson, Sophie. 2006. The Post Suburban Metropolis: Western Sydney and the Importance of Public Space Paper read at After Sprawl: Post-Suburban Sydney, at Parramatta, Nsw.

- 2009. 'The Magic of the Marketplace: Sociality in a Neglected Public Space.' Urban Studies no. 46:1577-1591.

Werbner, Pnina. 1999. 'Global Pathways: Working Class Cosmopolitans and the Creation of Transnational Ethnic Worlds.' Social Anthropology no. 7 (1):17-35.

- 2006. 'Vernacular Cosmopolitanism.' Theory, Culture Society no. 23 (23): $496-498$.

Wessendorf, Susanne. 2010. Commonplace Diversity: Social Interactions in a Super-diverse Context. Working Papers, Max Planck Institute for the Study of Religious and Ethnic Diversity, http://www.mmg.mpg.de/publications/workingpapers/2010/wp-10-11/. 
Williamson, Rebecca. 2015. Mundane Multiculture: Belonging as Spatial Practice in Suburban Sydney, Department of Sociology and Social Policy, University of Sydney, Sydney.

Wise, Amanda. 2009. 'Everyday Multiculturalism: Transversal Crossings and Working Class Cosmopolitans.' In Everyday multiculturalism, edited by A. Wise and Selvaraj Velayutham. Houndmills, Basingstoke, Hampshire; New York, NY: Palgrave.

Wise, Amanda, and Selvaraj Velayutham. 2009. 'Introduction: Multiculturalism and Everyday Life.' In Everyday Multiculturalism, edited by Amanda Wise and Selvaraj Velayutham. Basingstoke, Hampshire; New York: Palgrave Macmillan. 